\title{
Assessment of yield and quality of winter barley grain in southern Russia
}

\author{
Khamid Malkanduev, Rustam Shamurzaev, and Aminat Malkandueva \\ Branch of the Kabardino-Balkarian Scientific Center of the Russian Academy of Sciences, 224, Kirova \\ Street, 360004 Nalchik, Kabardino-Balkarian Republic
}

\begin{abstract}
A new high yielding winter barley of Madar variety is presented. One of the main conditions to obtain high yields is the use of new varieties adapted to the climatic conditions of a particular region. Therefore, the objective of our research, when creating the variety, was to increase productivity by improving adaptive properties and elements of productivity of plants and heads. As a result of joint work with breeders of FSBSI of the National Center of Grain named after P.P. Lukyanenko a new variety of winter barley Madar for forage direction was created, with a potential yield of more than $80 \mathrm{dt} / \mathrm{ha}$. For the years of the comparative testing at FSBSI of the National Center of Grain named after P.P. Lukyanenko by predecessors sunflower, winter wheat and white mustard, yields of the variety were 118.7 $\mathrm{dt} / \mathrm{ha} ; 87.5$ and $68.4 \mathrm{dt} / \mathrm{ha}$ respectively. In the tests on seeding time, yields in the variety ranged from 65.3 to $81.7 \mathrm{dt} / \mathrm{ha}$. The new variety is resistant to lodging, winterhardiness and drought resistance. The variety is suitable for cultivation according to all technologies; it can be cultivated in all zones of Russia. The estimated economic effect of the new variety is an increase in yields from 3 to $8 \mathrm{dt} / \mathrm{ha}$.
\end{abstract}

\section{Introduction}

Winter barley is the most important fodder, food and industrial crop, which has a significant share in the structure of sown areas of grain crops in the Russian Federation. It is widely cultivated all around the world and has an area of about 60 million ha. In the Russian Federation, the Southern and North Caucasian Federal Districts are the main cultivating regions [1].

Growth in grain production remains a major problem for the development of Russia AIC, including the North Caucasus, and winter barley is one of the most productive crops in the area. It makes better use of autumn-winter moisture reserves, uses them more sparingly, gives a much higher yield than the spring one, making cultivation of this crop more profitable [2].

The main challenge in creating a new variety is not only to use new and better specimens for hybridization, but also to create a local breeding material that is adaptable to specific conditions. Only in this way can work on the further improvement of breeding methods and the development of new varieties [3].

Winter barley has several advantages over spring barley and other grain crops. It is capable of producing grain yields that are on average by 1.6 times exceeding the yield of spring barley, and in some years by 1.9-3.0 times. Increasing grain yields is an important 
condition for crop production. There are two main lines for solving this problem. First, the creation of new high yielding varieties and second, the improvement of their cultivation technology [4].

The role of the variety in increasing crop yields is indisputable. New varieties approved for use in a region have higher yields or other agronomic characters. The rapid introduction of new high yielding varieties in production will lead to a minimum of $20-30 \%$ increase in product yields [5].

A significant role in grain balance is attributed to barley as a particularly valuable culture of versatile use (fodder, beer, cereal, green feed, hay, etc.), which occupies the second place. In the structure of sown areas, it is allocated between $15 \%$ and $30 \%$ [6].

In the study of the gene pool of the source material, it is important to choose the right selection criteria, taking into account the conditions of the environment. For this purpose, it is recommended to test varieties on different background and under different environmental conditions. Such studies enhance knowledge of ecological and geographical variability and species response rates, allowing to distinguish forms with agronomic characters [7].

Extensive technologies cannot be discarded with limited material resources since on fertile soils, well-fertilized predecessors, under normal weather conditions and timely and high-quality operations in the North Caucasus region, winter crops are capable of grain yielding more than $3 \mathrm{t} / \mathrm{ha}$ [8].

Taking into account the clear advantage of winter barley in terms of crop yields over spring barley and the observed climate warming, in order to increase gross grain production at the same cost, it is advisable in the southern region of the Russian Federation to increase the seeding area up to 1 million ha. The proposed production of new highly adaptive barley varieties and advanced crop agronomic techniques will be more conducive to a successful resolution of this issue [9].

Drought is an important factor limiting crop production in arid and semi-arid environments. Therefore, the use of high yielding drought-resistant varieties is an effective approach to reduce its harmful effects. Growing barley in drylands requires a reliable assessment of the variability of drought-resistance among breeding varieties. These varieties can also be used in barley breeding programs to increase drought-resistance [10.11.12].

\section{Materials and Methods}

Ecological varieties were carried out according to the methodology of the State Commission for the Testing and Protection of Breeding Achievements, the method of ecological grading of grain crops of FSBSI of the National Center of Grain named after P.P. Lukyanenko, the field experiment technique (B.A. Dospekhov, 1985) on the basis of the Institute of Agriculture KBSC RAS, in the steppe zone of the Kabardino-Balkarian Republic, in the conditions of the Krasnodar and Stavropol territories, the Republic of Crimea [13,14,15].

The registered area of the plots is $25 \mathrm{~m}^{2}$, repetition is 3 -fold, the predecessor - peas, the seeding rate is 4.0-4.5 million seedlings per 1 ha. Mineral fertilizers at a dose of $\mathrm{N}_{60} \mathrm{P}_{60} \mathrm{~K}_{30}$ were used for basic tillage. Feeding with a dose of $\mathrm{N}_{30}$ was carried out in the tube exit phase. The seeding was carried out by Klen- 1.5 seed planter. The harvesting was carried out with a Terrion-2010 combine.

\section{Results and discussion}

The Madar fodder winter barley is obtained by intra-specific hybridization and individual selection from a combination of 386-2/Parallelum 1633, 386-2(330-1/Kozyr), 330-1 (Radikal/Birgit). The variety plant height reaches $110 \mathrm{~cm}$, resistance to lodging is high - 5 
points, the number of grains in the head - 59 pcs. Winterhardiness is $100 \%$, drought resistance is high - 5 points. Grain unit - $684 \mathrm{~g} / \mathrm{l}$, weight of 1,000 grains - $38.9 \mathrm{~g}$, protein content $10.3 \%$. The growing season is 250 days. The variety has average field resistance to mildew, net blotch, has tolerance to leaf rust, susceptible to smut types.

In the ecological test of the Institute of Agriculture of the Kabardino-Balkarian Scientific Center of the Russian Academy of Sciences (steppe zone of the Kabardino-Balkarian Republic, 2018-2020), the average yield of the Madar variety was $51.4 \mathrm{dt} / \mathrm{ha}$ or exceeding the Samson standard of $7.7 \mathrm{dt} / \mathrm{ha}$. The Insar variety exceeded the Samson standard by 2.3 $\mathrm{dt} / \mathrm{ha}$. In the Madar variety, on average for three years, it was obtained $5.4 \mathrm{dt} / \mathrm{ha}$ more compared to Insar variety. The maximum yield by varieties was obtained in $2018,54.7 \mathrm{dt} / \mathrm{ha}$ were obtained for the Madar variety (Table 1).

Table 1. Yield of winter barley varieties in Kabardino-Balkarian Republic steppe zone (according to the Institute of Agriculture of the Kabardino-Balkarian Scientific Center of the Russian Academy of Sciences, the predecessor was a pea, 2018-2020)

\begin{tabular}{|l|c|c|c|c|c|}
\hline \multirow{2}{*}{ Variety/line } & \multicolumn{5}{|c|}{ Yield, dt/ha } \\
\cline { 2 - 6 } & $\mathbf{2 0 1 8}$ & $\mathbf{2 0 1 9}$ & $\mathbf{2 0 2 0}$ & Medium & 土 to the standard \\
\hline Samson, (st) & 48.3 & 37.0 & 45.8 & 43.7 & - \\
\hline Madar & 54.7 & 45.7 & 53.8 & 51.4 & +7.7 \\
\hline Insar & 49.3 & 42.5 & 46.1 & 46.0 & +2.3 \\
\hline LSD 05 & 2.9 & 3.2 & 3.0 & & \\
\hline
\end{tabular}

Under production conditions (Kabardino-Balkarian Republic foothill zone, Nartan village, 2018-2020) $50.0 \mathrm{dt} /$ ha were obtained from an area of more than 150 ha for the Madar variety.

In conditions of Krasnodar territory in 2015-2017 the new Madar winter barley variety exceeded the standard Samson variety by $9.3-18.8 \mathrm{dt} / \mathrm{ha}$, Rubezh variety by $2.5-12.1 \mathrm{dt} / \mathrm{ha}$. An even higher yield of $92.2 \mathrm{dt} / \mathrm{ha}$ was obtained at the North Kuban Experimental Station. The maximum yield in the Krasnodar territory for the Madar winter barley variety was obtained in 2015, which amounted to 98.2 and $98.8 \mathrm{dt} /$ ha (Table 2).

Table 2. Yields of winter barley varieties in the Krasnodar territory (according to the National Center of Grain named after P.P. Lukyanenko, 2015-2017)

\begin{tabular}{|l|c|c|c|c|c|}
\hline \multicolumn{2}{|c|}{ Variety/line } & \multicolumn{3}{|c|}{ Yield, dt/ha } \\
\cline { 2 - 6 } & $\mathbf{2 0 1 5}$ & $\mathbf{2 0 1 6}$ & $\mathbf{2 0 1 7}$ & Medium & $\begin{array}{c} \pm \text { to the } \\
\text { standard }\end{array}$ \\
\hline Samson, st & & & & & \\
\hline Rubezh & 86.6 & 66.0 & 67.3 & 73.3 & - \\
\hline Madar & 94.8 & 67.5 & 78.2 & 80.1 & +6.8 \\
\hline $\begin{array}{l}\text { Madar (North Kuban Agricultural Experimental } \\
\text { Station) }\end{array}$ & 98.8 & 88.2 & 89.2 & 92.2 & +18.9 \\
\hline \begin{tabular}{l} 
LSD 05 \\
\hline
\end{tabular} & 3.2 & 3.5 & 3.3 & & \\
\hline
\end{tabular}

According to the grain quality, the Madar variety in the conditions of Krasnodar territory on average for the period from 2015 to 2017 was at the level of the Samson standard. The protein content of grains in Madar variety ranged from $9.6 \%$ to $10.8 \%$, the weight of 1,000 
grains from 35.8 to $40.7 \mathrm{~g}$, at $10.2 \%$ to $10.5 \%$ and $40.5 \mathrm{~g}$ to $41.7 \mathrm{~g}$ in Samson variety, respectively. By weight of 1,000 grains, the Madar winter barley variety, on average, was inferior to the Samson variety by $2.9 \mathrm{~g}$. Compared to the best similar variety of winter barley Rubezh, the Madar variety, on average for three years, was at its level, both in protein content and in weight of 1,000 grains (Table 3).

Table 3. Grain quality of winter barley varieties (according to the National Center of Grain named after P.P. Lukyanenko, 2015-2017)

\begin{tabular}{|l|c|c|c|c|c|c|c|c|}
\hline Variety & \multicolumn{2}{|c|}{$\mathbf{2 0 1 5}$} & \multicolumn{2}{c|}{$\mathbf{2 0 1 6}$} & \multicolumn{2}{|c|}{ 2017 } & \multicolumn{2}{c|}{ average } \\
\cline { 2 - 9 } & $\begin{array}{c}\text { Protein, } \\
\mathbf{\%}\end{array}$ & $\begin{array}{c}\text { Weight of } \\
\mathbf{1 , 0 0 0} \\
\text { grains, }\end{array}$ & $\begin{array}{c}\text { Protein, } \\
\mathbf{\%}\end{array}$ & $\begin{array}{c}\text { Weight } \\
\text { of } \mathbf{1 , 0 0 0} \\
\text { grains } \\
\mathbf{g}\end{array}$ & $\begin{array}{l}\text { Protei } \\
\mathbf{n} \\
\mathbf{\%}\end{array}$ & $\begin{array}{c}\text { Weight of } \\
\mathbf{1 , 0 0 0} \\
\text { grains, }\end{array}$ & $\begin{array}{l}\text { Protei } \\
\mathbf{n ,} \\
\mathbf{\%}\end{array}$ & $\begin{array}{c}\text { Weight of } \\
\mathbf{1 , 0 0 0} \\
\text { grains, }\end{array}$ \\
\hline Samson, st & 10.5 & 41.7 & 10.5 & 40.5 & 10. & 43.2 & 10.4 & 41.8 \\
\hline Rubezh & 9.7 & 39.1 & 10.3 & 35.4 & 10. & 38.4 & 10.2 & 37.6 \\
\hline Madar & 9.6 & 40.7 & 10.6 & 35.8 & 10. & 40.2 & 10.3 & 38.9 \\
\hline
\end{tabular}

Under conditions of insufficient moisture in the Kabardino-Balkarian Republic, the protein content in the grain of the Madar variety varied from $12.2 \%$ to $12.7 \%$, while in the Samson standard these indicators varied from $11.3 \%$ to $12.5 \%$. On average over three years, the Madar variety exceeded the standard by $0.6 \%$. Among the studied varieties in terms of protein content, the Insar variety is notable - $12.9 \%$ (Table 4 ).

Table 4. Grain quality of new winter barley varieties of the Institute of Agriculture of the KabardinoBalkarian Scientific Center of the Russian Academy of Sciences

(Kabardino-Balkarian Republic steppe zone, predecessor was peas, 2018-2020)

\begin{tabular}{|c|c|c|c|c|c|c|c|c|}
\hline \multirow[t]{2}{*}{ Variety } & \multicolumn{2}{|r|}{2018} & \multicolumn{2}{|r|}{2019} & \multicolumn{2}{|r|}{2020} & \multicolumn{2}{|r|}{ average } \\
\hline & $\begin{array}{c}\text { Protein } \\
\% \\
\%\end{array}$ & $\begin{array}{c}\text { Weight of } \\
1,000 \\
\text { grains, g }\end{array}$ & $\begin{array}{c}\text { Protei } \\
\text { n, } \\
\%\end{array}$ & $\begin{array}{c}\text { Weight of } \\
1,000 \\
\text { grains, } g\end{array}$ & $\begin{array}{c}\text { Protei } \\
\text { n, } \\
\%\end{array}$ & $\begin{array}{c}\text { Weight of } \\
1,000 \\
\text { grains, } g\end{array}$ & $\begin{array}{c}\text { Protei } \\
\text { n, } \\
\% \\
\end{array}$ & $\begin{array}{c}\text { Weight of } \\
1,000 \\
\text { grains, } g\end{array}$ \\
\hline Samson, st & 11.9 & 40.3 & 12.5 & 41.2 & 11.3 & 48.5 & 11.9 & 43.3 \\
\hline Insar & 11.4 & 41.0 & 12.8 & 36.4 & 14.4 & 38.9 & 12.9 & 38.8 \\
\hline Madar & 12.2 & 42.7 & 12.5 & 38.5 & 12.7 & 46.0 & 12.5 & 42.4 \\
\hline
\end{tabular}

When assessing the grain quality of the Madar variety in the Krasnodar territory and Kabardino-Balkaria, it can be noted that on average, in terms of protein content and weight of 1,000 grains, the variety had advantages in the conditions of Kabardino-Balkarian Republic. In terms of protein content, the excess was $2.2 \%$ and in terms of weight of 1,000 grains was $3.5 \mathrm{~g}$.

In the study of a Madar winter barley variety at the various plots of the Russian Federation, positive results were obtained. Thus, when tested in the conditions of the Crimea for the Madar variety, the yield exceeded the standard Kondrat variety by $2.5 \mathrm{dt} / \mathrm{ha}$, the excess by the weight of 1,000 grains was $2.1 \mathrm{~g}$. In terms of lodging and drought resistance, the variety was at the standard level. The Madar variety exceeds the Kondrat variety in height by $4.6 \mathrm{~cm}$ (Table 5).

Table 5. Comparative assessment of winter barley varieties at variety plots (2018-2020)

\begin{tabular}{|l|c|c|c|c|c|}
\hline Variety & $\begin{array}{c}\text { Crop yield, } \\
\text { dt/ha }\end{array}$ & $\begin{array}{c}\text { Plant height, } \\
\mathbf{c m}\end{array}$ & $\begin{array}{c}\text { Forage } \\
\mathbf{1 , 0 0 0} \\
\text { grains, }\end{array}$ & $\begin{array}{c}\text { Lodging } \\
\text { resistance, } \\
\text { point }\end{array}$ & $\begin{array}{c}\text { Lodging } \\
\text { resistance, } \\
\text { point }\end{array}$ \\
\hline \multicolumn{6}{|c|}{ Republic of Crimea } \\
\hline Kondrat, st & 57.4 & 89.2 & 34.2 & 5 & 5
\end{tabular}


Table 5. Continued.

\begin{tabular}{|c|c|c|c|c|c|}
\hline Madar & 59.7 & 93.8 & 36.3 & 4.5 & 4 \\
\hline LSD $_{05}$ & \multicolumn{7}{|c|}{ Stavropol Territory } \\
\hline \multicolumn{7}{|c|}{} & \multicolumn{7}{|c|}{4} & 4 \\
\hline $\begin{array}{c}\text { Average } \\
\text { standard }\end{array}$ & 50.3 & 83.3 & 38.7 & 4 & 4 \\
\hline Madar & 56.5 & 91.7 & 39.7 & 4 & \\
\hline LSD $_{05}$ & & & & & 4 \\
\hline
\end{tabular}

For the Stavropol region in terms of yields, Madar variety exceeded the standards on average years of research by $6.2 \mathrm{dt} / \mathrm{ha}$, by weight of 1,000 grains per $1.0 \mathrm{~g}$, by plant height by $8.4 \mathrm{~cm}$. In terms of lodging and drought resistance, the Madar winter barley variety was at the standard level.

In terms of disease resistance, the Madar winter barley variety has an average field resistance to mildew, net blotch, has tolerance to leaf rust, susceptible to smut types (Table $6)$.

Table 6. Disease incidence, $\%$

(according to the National Center of Grain named after P.P. Lukyanenko, 2015-2017)

\begin{tabular}{|c|c|c|c|c|c|c|c|c|c|}
\hline \multirow{2}{*}{$\begin{array}{c}\text { Causal agent } \\
\text { agent }\end{array}$} & \multicolumn{3}{|c|}{ Madar } & \multicolumn{3}{|c|}{ Samson, st } & \multicolumn{3}{|c|}{ Indicator variety } \\
\hline & 2015 & 2016 & 2017 & 2015 & 2016 & 2017 & 2015 & 2016 & 2017 \\
\hline \multicolumn{10}{|l|}{$\begin{array}{l}\text { In competitive variety } \\
\text { testing }\end{array}$} \\
\hline Rust types: & & & & & & & \multicolumn{3}{|c|}{ Mikhailo } \\
\hline leaf rust & 0 & 0 & 0 & 0 & 0 & 0 & 0 & 0 & 5 \\
\hline \multicolumn{10}{|l|}{ Smut types: } \\
\hline & & & & & & & \multicolumn{3}{|r|}{ Sekret } \\
\hline head smut & 0 & 0 & 0 & 0 & 0 & 0 & 0 & 0 & 0 \\
\hline \multirow[t]{2}{*}{ kernel smut } & 0 & 0 & 0 & 0 & 0 & 0 & 0 & 0 & 0 \\
\hline & & & & & & & \multicolumn{3}{|c|}{ Dobrynya 3} \\
\hline \multirow[t]{2}{*}{ mildew } & 5 & 0 & 15 & 0 & 0 & 10 & 15 & 20 & 30 \\
\hline & & & & & & & \multicolumn{3}{|c|}{ Kondrat } \\
\hline root rot & 10 & 15 & 15 & 30 & 50 & 30 & 30 & 50 & 50 \\
\hline \multicolumn{10}{|l|}{$\begin{array}{l}\text { With artificial } \\
\text { infection: }\end{array}$} \\
\hline & & & & & & & \multicolumn{3}{|c|}{ Mikhailo } \\
\hline \multirow[t]{2}{*}{ leaf rust } & 20 & 30 & 30 & 20 & 40 & 30 & 50 & 50 & 70 \\
\hline & & & & & & & & & Sekret \\
\hline head smut & 15.8 & 12.0 & 9.7 & 16.5 & 12.5 & 10.4 & 22.4 & 17.2 & 10.4 \\
\hline \multirow[t]{2}{*}{ kernel smut } & 4.5 & 4.7 & 4.0 & 4.0 & 3.8 & 4.2 & 6.7 & 7.2 & 5.4 \\
\hline & & & & & & & \multicolumn{3}{|c|}{ Dobrynya 3} \\
\hline \multirow[t]{2}{*}{ mildew } & 50 & 30 & 55 & 50 & 30 & 60 & 50 & 50 & 70 \\
\hline & & & & & & & \multicolumn{3}{|c|}{ Romans } \\
\hline net blotch & 50 & 30 & 50 & 70 & 50 & 50 & 80 & 60 & 80 \\
\hline
\end{tabular}

The Madar winter barley is resistant to root rots, on average over three years, the susceptibility was $10-15 \%$, with $30-50 \%$ for the Samson standard and Kondrat indicator variety. The susceptibility to leaf rust of the Madar variety was at the level of 20-30\%, while the Mikhailo indicator variety was $50-70 \%$. On average, during the years of research, the susceptibility of Madar variety with mildew at the level of $30-55 \%$, with the susceptibility of 
Dobrynya 3 by $50-70 \%$, and the Samson standard by $30-60 \%$. The susceptibility to the net blotch of the new Madar variety varied between 30 and $50 \%$ during the research period, with the Romans indicator variety by $60-80 \%$ and the Samson standard by $50-70 \%$.

The bush of the Madar winter barley variety has an intermediate shape, the stem is medium, hollow, strong. The head is cylindrical, of medium length, straw-yellow, the density of the segments of the head is 16-18. Glume is small, narrow, nervation is weak. The leaf is not pubescent, with a weak wax bloom during tillering, dark green in color, intermediate type. The color of the stem nodes is brownish, the ears are sickle-shaped, the tongue is ordinary. The awns are long, half-pressed, straw-yellow in color. The grain is medium in size, the base of the grain is bare, the character of the seta at the base of the grain is short. The main morphological feature of the new variety, which makes it possible to distinguish it from other varieties is a very weak anthocyanin coloration of the ears, a strong wax bloom on the spathe. Tilling capacity of the variety is 2.8 , resistance to lodging - 5 points, ability to shed and brittleness of the head, the degree of flagging of the head - 1 point, resistance to germination at the root - 5 points, resistance to soaking and damping off - 5 points. The variety is highly resistant to autumn and spring frosts (5 points). The critical freezing temperature for the Madar winter barley variety is $-14 \mathrm{C}$. The grain has good thrashing capacity.

The most important distinctive biological characteristics of the variety are ear formation two days earlier than the standard Samson variety, possessing an elastic, strong straw, and high lodging resistance. The optimum seeding rate for the Madar variety is $140-160 \mathrm{~kg} / \mathrm{ha}$.

\section{Conclusion}

The search and attraction of created sources in breeding programs aimed at increasing the productivity and adaptability of winter barley will allow to develop a new breeding material for highly productive varieties.

The main advantages of the new variety Madar are expressed in an increase in yield over the standards by $6-18 \mathrm{dt} / \mathrm{ha}$. In terms of grain quality indicators, the new variety exceeds the standards or is at their level.

The estimated economic effect from the use of the Madar variety is on average 3-8 dt/ha higher compared to the standards.

The tests performed in the conditions of the North Caucasus (6) region make it possible to recommend the Madar variety for wide use in breeding programs and for implementation into production. The variety is included in the State Register of Breeding Achievements of the Russian Federation in 2020 and is protected by a patent. The variety differs in high yields, resistance to lodging, higher productivity of plants and heads, average frost resistance. Suitable for cultivation in the southern regions of Russia.

\section{References}

1. N. V. Repko, K. V. Smirnova, K. V. Sukhinina, A. S. Koblensky, Scientific Journal of KubSAU, 1 (2016)

2. Kh. A. Malkanduev, N. V. Serkin, A. Kh. Malkandueva, R. I. Shamurzaev, V. V. Nesterenko, News of Kabardino-Balkarian Scientific Center of RAS, 39 (2020)

3. A. A. Bisharev, V. A. Shevchenko, I. A. Kalyakulina, M. A. Dyuldina, Izvestia RAS SamSC, 612 (2017)

4. A. A. Bisharev, V. A. Shevchenko, V. A. Zheleznikova, I. A. Kalyakulina, M. A. Dyuldina, Izvestia RAS SamSC. 478 (2018) 
5. N. V. Repko, K. V. Smirnova, A. S. Koblensky, Scientific Journal of KubSAU, 1 (2015)

6. E. G. Filippov, A. A. Dontsova, D. P. Dontsov, A. A. Bulanova, Agrarnyi vestnik Urala, 75 (2017)

7. I. S. Sysenko, S. I. Novoseletsky, O. E. Patseka, Scientific Journal of KubSAU, 1 (2016)

8. A. S. Ereshko, V. B. Khronyuk, N. V. Repko, Vestnik agrarnoj nauki Dona, 57 (2012)

9. Yu. P. Pryadun, Izvestia Orenburg State Agrarian University, 84 (2019)

10. Mahdi Zare, African Journal of Biotechnology, 15975 (2012)

11. Mehdi Feizi, Mahmood Solouki, Behzad Sadeghzadeh, BaratAli Fakheri, Seyed Abolghasem Mohammadi, Bioscience Journal, 1518 (2020)

12. Saeideh Dorostkar, Hassan Paknyiat, Mahmood Ahmadi Kordshooli, Raziyeh Ghorbani, Massumeh Aliakbari, Neda Sobhanian, Reza Valiloo, Science Research, 26 (2016)

13. Methodology of state variety testing of agricultural crops, 2 (1989)

14. N. I. Dzhelali, Guidelines for ecological variety testing of grain crops (1985)

15. B. A. Dospekhov, Field experiment technique (1985) 